\title{
Chemical characterization of the species Raphanus sativus L. under different conditions of fertilization and water stress conditions
}

\author{
Amanda Lima Cunhaa, Marília Layse Alves Costaa, Tereza Lucio Gomes Quirino Maranhãob, \\ Mabel Alencar do Nascimento Rochac, Alex Teófilo da Silvac, Cícera Maria Alencar do \\ Nascimento ${ }^{d}$, Mayara Andrade Souzae, Tâmara Cláudia de Araújo Gomesf, João Gomes da \\ Costa ${ }^{f}$, Aldenir Feitosa dos Santosc,e \\ a Programa de Pós-Graduação em Agricultura e Ambiente, Universidade Federal de Alagoas, Arapiraca, 57309-005, Alagoas, Brazil. \\ *amandalima2012.quimica@gmail.com \\ ${ }^{b}$ Escola Municipal Professor Donizett Calheiros, Maceió, 57082-010, Alagoas, Brazil. \\ c Universidade Estadual de Alagoas, Arapiraca, 57312-000, Alagoas, Brazil. \\ ¿ Universidade Estadual de Ciências da Saúde de Alagoas, Maceió, 57010-001, Alagoas, Brazil. \\ e Programa de Pós-Graduação em Análise de Sistemas Ambientais, Centro Universitário CESMAC, Maceió, 57051-160, Alagoas, \\ Brazil. \\ f Centro de Pesquisa Agropecuária dos Tabuleiros Costeiros, Embrapa Tabuleiros Costeiros, Rio Largo, 57100-000, Alagoas, Brazil.
}

Received: August 16, 2019 / Accepted: Semptember 21, 2019 / Published online: January 20, 2020

\begin{abstract}
This study quantifies phenolic and flavonoid compounds and evaluates the antioxidant activity by the DPPH (2,2-diphenyl-1picrylhydrazyl) method, also identifying some secondary metabolites of $R$. sativus under organic fertilization and water stress. For this, a greenhouse experiment was carried out with the preparation of plant extracts (leaves and roots), quantification of phenolic and flavonoid compounds, analysis of antioxidant activity, and phytochemical screening. Different classes of secondary metabolites (catechins, steroids, saponins, among others) were identified. The DPPH method showed that the leaf extract has higher DPPH radical scavenging activity. The leaf extract had a high content of phenolic compounds, especially in treatments without water stress, either with organic fertilization (1925.59 mg GAE/g extract) or with mineral fertilization (2058.47 mg GAE/g extract). For root extracts, R. sativus developed under water stress and organic fertilization showed higher phenolic content (1383.24 mg GAE/g extract). Regarding flavonoid content, the root extract that showed the highest concentration corresponded to the treatment under water stress and without fertilization ( $82.1 \mathrm{mg}$ QE/g extract). Therefore, radish was shown to be rich in bioactive compounds and with antioxidant potential in both its leaves and roots.
\end{abstract}

Keywords: Antioxidant, flavonoids, radish, phenolic compounds, phytochemical screening.

\section{Caracterização química da espécie Raphanus sativus L. submetida à diferentes condições de adubação e estresse hídrico}

\begin{abstract}
Resumo
Este estudo quantificou o teor de compostos fenólicos e flavonóides, avaliou a atividade antioxidante pelo método DPPH (2,2difenil-1-picrilhidrazil) e identificou alguns metabólitos secundários do $R$. sativus submetido a adubação orgânica e estresse hídrico. Foi realizado experimento em casa de vegetação e preparo dos extratos vegetal (folha e raiz), quantificação de compostos fenólicos e flavonóides, atividade antioxidante e a triagem fitoquímica. Foram identificadas diferentes classes de metabólitos secundários (catequinas, esteróides, saponinas entre outras). Pelo método DPPH foi demonstrado que o extrato das folhas possuem maior eficiência quanto a captura do radical DPPH. O extrato das folhas apresentaram alto teor de compostos fenólicos, especialmente nos tratamentos sem estresse hídrico, seja com adubação orgânica (1925,59 mg EAG/g de extrato) ou com adubação mineral (2058,47 mg EAG/g de extrato). Para a raiz, a $R$. sativus desenvolvida sob estresse hídrico e adubação orgânica apresentou maior teor de fenóis $(1383,24 \mathrm{mg}$ EAG/g de extrato). Para o teor de flavonóides o extrato da raiz que apresentou maior concentração foi o estresse hídrico sem adubação (82,1 mg EQ/g de extrato). Portanto, foi possível observar que o rabanete é rico em compostos bioativos e com potencial antioxidante, tantos suas folhas como em sua raiz.
\end{abstract}

Palavra-chave: Antioxidante, flavonoides, rabanete, compostos fenólicos, triagem fitoquímica.

\section{Introduction}

The species Raphanus sativus L., belonging to the family
Brassicaceae, originates from the Mediterranean and is popularly known as radish. Its family comprises other known 
vegetables such as broccoli, kale, cabbage, and cauliflower. The edible part is a tuberous root of bright scarlet color, with white pulp. Moreover, the species has a short cycle, lasting approximately 25 to 35 days (Dutra, Deboni, Volpi, Matias, \& Nesi, 2014).

Due to its rapid development, the radish crop requires greater attention regarding nutrition and irrigation. Soil fertility is one of the primary criteria for the development of this crop (Coutinho Neto, Orioli Júnior, Cardoso, \& Coutinho, 2010).

In addition to the commercial and ecological benefits, organic fertilization interferes with the production of secondary metabolites, which are compounds produced during plant metabolism, originating from the plant-environment relationship. These compounds provide different species with bioactive activity, being effective in medicinal treatments (Bomfim, Lima, Vianelo, \& São José, 2017).

The presence of secondary metabolites in plant species also characterizes antioxidant activity, which is defined as the ability to minimize the oxidative action of free radicals. Free radicals are atoms or molecules that have an unpaired electron in their valence shell, which gives them high reactivity. Their excess in the environment triggers a series of reactions (called oxidative stress) that can lead to DNA mutation, cell death, cardiovascular disease, Alzheimer's disease, Parkinson's disease, aging, among others (Santos et al., 2019).

According to Singh and Singh (2013), radish is a species rich in bioactive compounds such as sulforaphene (found in its seeds) that can act against the bacteria Streptococcus, Pyrococcus, Pneumococcus, and Escherichia coli. Furthermore, its tuberous roots are rich in metabolites such as vanillic acid, caffeic acid, p-coumaric acid, pyruvic acid, among others. Thus, it can act to combat liver and gallbladder disorders, headache, insomnia, and diarrhea, also being an alternative source for the treatment of cancer and AIDS.

In addition, species belonging to the family Brassicaceae have a group of secondary metabolites called glucosinolates. In plants, glucosinolates act in defense against pathogens, in sulfur and nitrogen metabolism, and in growth regulation. They are also critical in defense against environmental factors such as high temperatures. In the human body, glucosinolates act as antioxidant and anticarcinogenic agents. Products derived from hydrolysis in this group stand out as chemopreventive agents (especially against prostate cancer), besides interfering with glycemic index control and cardiovascular problems (Valério, 2017).

This study quantified phenolic and flavonoid compounds and evaluated the antioxidant activity by the DPPH (2,2diphenyl-1-picrylhydrazyl) method, also identifying some secondary metabolites of radish under organic fertilization and water stress.

\section{Materials and Methods}

\section{Site and soil characterization}

The experiment was conducted in a greenhouse at the Federal University of Alagoas - UFAL, Arapiraca Campus. The geographical coordinates are: $9^{\circ} 41^{\prime} 55.7^{\prime} \mathrm{S}$ latitude and $36^{\circ} 41^{\prime} 08.7$ " W longitude.
The soil used for the experiment was collected near the greenhouse. The samples were collected in a zigzag pattern and chemical characteristics were determined, with the following results (in mg. $\mathrm{dm}^{-3}$ ): $\mathrm{Na}=48 ; \mathrm{P}=13 ; \mathrm{k}=105 ; \mathrm{Ca}$ $=1.4 ; \mathrm{Mg}=0.7 ; \mathrm{Ca}+\mathrm{Mg}=2.1 ; \mathrm{Al}=0.00 ; \mathrm{H}+\mathrm{Al}=2.3 ; \mathrm{Zn}$ $=7.7 ; \mathrm{Fe}=44.4 ; \mathrm{Mn}=37.8 ; \mathrm{Cu}=4.5 ; \mathrm{B}=0.3 ; \mathrm{S}=40.3$. In addition, other soil characteristics were quantified, namely: $\mathrm{pH}$ in water $=5.6$; sum of bases $=2.58$; effective cation exchange capacity $=2.58$ (at $\mathrm{pH}=2.88$ ); base saturation index $(\%)=73.6$; organic matter $=1.6 \mathrm{dag} \mathrm{kg}^{-1}$.

\section{Description of the experiment and extract preparation}

The design was completely randomized (CRD), with each treatment consisting of five replicates (pots) and each pot having four plants. The experiment consisted of six treatments (T): Water stress without fertilization (T1 - ESA); Water stress with organic fertilization (T2 - ECAO); Water stress with mineral fertilization (T3 - ECAM); No fertilization and no water stress (T4 - SASE); Organic fertilization without water stress (T5 - AOSE); and Mineral fertilization without water stress (T6 - AMSE). Fertilization was performed from the soil analysis and according to the recommendation for the radish crop (Sociedade brasileira de ciência do solo, 2004). To each pot containing mineral fertilizer was added $0.64 \mathrm{~g}$ urea $(44 \% \mathrm{~N}) ; 5.46 \mathrm{~g}$ single superphosphate $\left(18 \% \mathrm{P}_{2} \mathrm{O}_{5}\right)$; and $1.09 \mathrm{~g}$ potassium chloride $\left(58 \% \mathrm{~K}_{2} \mathrm{O}\right)$. To the pots containing organic fertilizer was added $77 \mathrm{~g}$ organic compound $(1.98 \% \mathrm{~N}, 1.85 \% \mathrm{P}$, and $0.179 \% \mathrm{~K}) ; 10.92 \mathrm{~g}$ Gafsa phosphate ( $9 \%$ citric acid-soluble $\left.\mathrm{P}_{2} \mathrm{O}_{5}\right)$; and $1.26 \mathrm{~g}$ potassium sulfate $\left(50 \% \mathrm{~K}_{2} \mathrm{O}\right)$. To all pots was added $1.5 \mathrm{~kg}$ soil.

Fertilization was performed 30 days before sowing so that the soil would come into contact with additional nutrients, allowing their greater absorption for subsequent sowing. In addition to the soil and nutrients, gravel was also added to cover the bottom of each pot, allowing water drainage in the pots. Four (4) seeds of radish cv. 'Gigante Siculo' were sown in each pot at a depth of two (2) cm.

The experiment was installed in a greenhouse for a period of 30 days. In the first two weeks, all vessels were manually irrigated in the morning. From day 15 onwards, the vessels that suffered water stress were irrigated every 48 hours.

The extracts of radish leaves and roots were prepared from the maceration process, which consisted of the immersion of approximately $50 \mathrm{~g}$ of dry material (milled by knife mill, NL - 226-01) in methanol (200 mL), with subsequent solvent removal by rotoevaporation (Fisatom $803)$. Every 48 hours, the material was filtered and stored in glass containers, and methanol added again. The extracts were stored in sealed glass containers and kept under refrigeration (Santos et al., 2019).

\section{Phytochemical screening}

Phytochemical screening was based on the methodology proposed by Santos et al. (2019), which has been performed to prospect the following allelochemicals: phenols, pyrogallic tannins, phlobaphenic tannins, anthocyanin and anthocyanidin, flavones, flavonols, xanthones, chalcones, aurones, flavononols, leucoanthocyanidins, catechins, 
flavonones, steroids, triterpenoids, and saponins.

An aliquot (leaf and root) was taken from each extract and diluted in a beaker with $35 \mathrm{~mL}$ of distilled water. Then, $3 \mathrm{~mL}$ of the solution was added to 7 test tubes. The 7 tubes were used to identify phenols, pyrogallic tannins, phlobaphenic tannins, anthocyanin and anthocyanidin, flavones, flavonols, xanthones, chalcones, aurones, flavononols, leucoanthocyanidins, catechins, and flavonones. To indicate the presence of steroids, triterpenoids, and saponins, $10 \mathrm{~mL}$ of the solution of each extract was heated on a heating plate until the material was completely dried.

Moreover, an alcoholic ferric chloride solution was used for identification of phenols, pyrogallic tannins, and phlobaphenic tannins. Color variation between blue and red indicates the presence of phenols, while a dark blue precipitate indicates the presence of pyrogallic tannins (hydrolysable tannins) and a green precipitate indicates the presence of phlobaphenic tannins (condensed or catechic tannins).

The presence of anthocyanins and anthocyanidins was indicated by red staining $(\mathrm{pH} 3$ with addition of $0.1 \mathrm{M}$ hydrochloric acid), lilac staining ( $\mathrm{pH} 8.5$ with addition of $0.1 \mathrm{M}$ sodium hydroxide), and blue staining ( $\mathrm{pH} 11$ with addition of $0.1 \mathrm{M} \mathrm{NaOH}$ ). In turn, the presence of flavones, flavonols, and xanthones was indicated by yellow color at $\mathrm{pH} 11$ (addition of $0.1 \mathrm{M} \mathrm{NaOH}$ ), and the presence of chalcones and aurones by red color at $\mathrm{pH} 3$ (addition of $0.1 \mathrm{M} \mathrm{HCl}$ ) and orange color at $\mathrm{pH} 11$ (addition of $0.1 \mathrm{M} \mathrm{NaOH}$ ). The presence of flavononols was indicated by red-orange color with the addition of $0.1 \mathrm{M}$ $\mathrm{NaOH}$ at $\mathrm{pH} 11$.

To indicate leucoanthocyanidins and catechins, the solution was acidified to $\mathrm{pH} 2$ with $0.1 \mathrm{M} \mathrm{HCl}$ and then lamp-heated for 3 minutes. The red color was indicative of leucoanthocyanidins and the yellow color indicated catechins.

The presence of flavonones was indicated by red-orange color at pH 11 with the addition of $0.1 \mathrm{M} \mathrm{NaOH}$, after a 3minute lamp heating.

The indication of flavonols, flavonones, flavononols, and xanthones occurred by the addition of $1 \mathrm{~mL}$ of concentrated $\mathrm{HCl}$ and a magnesium strip. The red color was indicative of such constituents.

After reaction of the dry residue with some decigrams of sodium sulfate, $1 \mathrm{~mL}$ of acetic anhydrous, and 3 drops of concentrated sulfuric acid, the appearance of blue color followed by permanent green color indicated the presence of steroids, while brown to red color indicated the presence of triterpenoids.

To identify saponins, the dry residue was homogenized with $8 \mathrm{~mL}$ of distilled water and stirred for 3 minutes. The appearance of foam was indicative of the presence of saponins.

\section{DPPH quantitative test, quantification of phenolic compounds and flavonoids}

The test was performed according to the methodology described by Santos et al. (2019), from $0.0020 \mathrm{~g}$ radish extract (leaf and tuber) in $20 \mathrm{~mL}$ methanol.

For that purpose, $0.0020 \mathrm{~g}$ of each extract was diluted in 20 $\mathrm{mL}$ methanol $(\mathrm{MeOH})$, with solutions prepared at concentrations of $5,10,25,50,125,250$, and $500 \mu \mathrm{g} \mathrm{mL} \mathrm{m}^{-1}$.
Readings were performed in triplicate. The sample solutions consisted of $2.5 \mathrm{~mL}$ of the stock solution and $1 \mathrm{~mL}$ of the 0.3 Mm DPPH solution. The blank solution contained $2.5 \mathrm{~mL}$ of sample solution and $1 \mathrm{~mL}$ of methanol $(\mathrm{MeOH})$, the negative consisted of $2.5 \mathrm{~mL}$ of methanol and $1 \mathrm{~mL}$ of DPPH solution. Soon after, the solutions were stored for 30 minutes in a box covered with dark paper.

The test was performed with the aid of a UV-VIS spectrophotometer (Shimadzu, UV-1280) with a wavelength of $518 \mathrm{~nm}$, in which absorbances were obtained and converted into antioxidant potential (AAO\%) using Equation: $\mathrm{AAO} \%=(100-($ Absorbance $\mathrm{A}-$ Absorbance B X 100))/Absorbance $C$.

The total phenolic content was quantified by the method described by Barros et al. (2018) with some adaptations. For the gallic acid calibration curve $\left(\mathrm{R}^{2}=0.995\right), 0.04 \mathrm{~g}$ of gallic acid was weighed in $8 \mathrm{ml} \mathrm{MeOH}$ (stock solution). From the $0.15 ; 0.1 ; 0.05 ; 0.025 ; 0.01$; and $0.005 \mathrm{mg} \mathrm{mL}^{-1}$ dilutions, the following procedures were performed (in triplicate - for each concentration): to a flask of amber glass was added $100 \mu \mathrm{L}$ of gallic acid test solution, $500 \mu \mathrm{L}$ of Folin-Ciocalteau reagent, and $1 \mathrm{~mL}$ distilled $\mathrm{H}_{2} \mathrm{O}$, the solution being vortexed for 1 minute. Subsequently, $2 \mathrm{~mL}$ of $15 \%$ sodium carbonate was added, the solution being vortexed for 30 seconds. To the final volume of the solution was added distilled water, until it reached $10 \mathrm{~mL}$. The solution was stored for 2 hours in a box covered with dark paper. A UV-VIS spectrophotometer (Shimadzu, UV-1280) with a wavelength of $750 \mathrm{~nm}$ was used to read the solutions.

The flavonoid quantification was performed according to the methodology of Barros et al. (2018). $1 \mathrm{mg}$ quercetin was weighed and diluted in $1 \mathrm{~mL} \mathrm{MeOH}$. Then, dilutions were made at concentrations of $0.03 ; 0.025 ; 0.020 ; 0.015 ; 0.01$; 0.005 ; 0.0025 ; and $0.00125 \mathrm{mg} \mathrm{mL}^{-1}\left(\mathrm{R}^{2}=0.99\right)$. From the dilutions, the following procedures were performed (in triplicate - for each concentration): $200 \mu \mathrm{L}$ of quercetin test solution and $100 \mu \mathrm{L}$ of $2 \%$ methanolic aluminum chloride solution were added. The well plate was then kept in the dark for 30 minutes. A UV-VIS spectrophotometer (Shimadzu, UV-1280) with a wavelength of $420 \mathrm{~nm}$ was used to read the solutions.

\section{Data analysis}

Analysis of variance was performed and the means of the quantification analyses of phenolic and flavonoid compounds were compared by the Scott-knot test at 5\% probability. For the data obtained from the DPPH radical scavenging test, analysis of variance followed by Scott-knot test at $5 \%$ probability was used. The statistical software Sisvar 5.6 was used for all statistical analyses.

\section{Results and discussion}

Phytochemical screening, antioxidant potential, phenolic compounds flavonoids content in $R$. sativus leaf and root extracts is described in Tables 1 and 2. R. sativus plants subjected to water stress had a higher amount of secondary metabolites, mainly phenolic compounds.

According to Sousa and Sousa (2017), plants subjected 
to water stress tend to produce more secondary metabolites, especially phenolic compounds; this higher concentration is a form of defense that plants develop to adapt to water stress.

From the results obtained, it is possible to suggest the medicinal potential of both radish leaves and roots. According to Schlickmann (2015), R. sativus has compounds with pharmacological potential, acting on liver disorders, prostate cancer, and antimutagenic activity. However, there is still little research on the phytotherapic potential of $R$. sativus.

In the ethanolic extract of leaves of the species Raphanus sativus var. oleiferus Metzg, Silva (2014) were identified the following classes: tannins, steroids, flavonoids, and polysaccharides.

Table 1. Secondary metabolites identified in radish leaf and root extracts under different growing conditions. Secondary
metabolite

Growing conditions

\begin{tabular}{cc||rrr}
\hline \multicolumn{3}{c||}{ Leaf } & & \multicolumn{2}{c}{ Root } \\
\hline ESA ECAO ECAM SASE AOSE AMSE & ESA ECAO ECAM SAS
\end{tabular}

ESA ECAO ECAM SASE AOSE AMSE ESA ECAO ECAM SASE AOSE AMSE

\begin{tabular}{|c|c|c|c|c|c|c|c|c|c|c|c|c|}
\hline Phenols & - & - & - & - & - & - & - & - & - & - & - & - \\
\hline Pyrogallic tannins & - & - & - & - & - & - & - & - & - & - & - & - \\
\hline $\begin{array}{l}\text { Phlobaphenic } \\
\text { tannins }\end{array}$ & - & - & - & - & + & + & + & - & - & - & + & + \\
\hline $\begin{array}{l}\text { Anthocyanin and } \\
\text { anthocyanidin }\end{array}$ & - & - & - & - & - & - & - & - & - & - & - & - \\
\hline $\begin{array}{l}\text { Flavones, flavonols, } \\
\text { and xanthones }\end{array}$ & - & + & - & + & + & + & - & - & - & + & + & + \\
\hline $\begin{array}{l}\text { Chalcones and } \\
\text { aurones }\end{array}$ & - & - & - & - & - & - & - & - & - & - & - & - \\
\hline Flavononols & - & - & - & - & - & - & - & - & - & - & - & - \\
\hline Leucoanthocyanidins & - & - & - & - & - & - & - & - & - & - & - & - \\
\hline Catechins & + & + & + & + & + & + & - & - & + & + & + & + \\
\hline Flavonones & - & - & - & - & - & - & - & - & - & - & - & - \\
\hline $\begin{array}{l}\text { Flavonols, } \\
\text { flavonones, and } \\
\text { xanthones }\end{array}$ & - & + & + & - & - & - & - & - & + & - & - & - \\
\hline Steroids & + & + & + & + & + & + & + & + & + & + & + & + \\
\hline Triterpenoids & - & - & - & - & - & - & - & - & - & - & - & - \\
\hline Saponins & + & + & + & - & - & - & + & + & + & - & - & - \\
\hline
\end{tabular}

Indicates presence (+) and indicates absence (-). Legend: ESA - Water stress without fertilization; ECAO - Water stress with organic fertilization; ECAM - Water stress with mineral fertilization; SASE - No water stress and no fertilization; AOSE - Organic fertilization without water stress; AMSE

- Mineral fertilization without water stress.

Table 2. Mean values of antioxidant potential $\left(250 \mu \mathrm{g} \mathrm{mL}^{-1}\right)$, phenolic compounds content (mg GAE g extract $\left.{ }^{-1}\right)$, and flavonoids content ( $\mathrm{mg}$ EQ g extract ${ }^{-1}$ ) in radish leaf and root extracts in the different treatments.

\begin{tabular}{|c|c|c|c|c|c|c|}
\hline \multirow{2}{*}{ Treatment } & \multicolumn{2}{|c|}{ Antioxidant potential } & \multicolumn{2}{|c|}{ Phenolic compounds content } & \multicolumn{2}{|c|}{ Flavonoids content } \\
\hline & Leaf & Root & Leaf & Root & Leaf* & Root \\
\hline $\begin{array}{l}\text { Water stress without } \\
\text { fertilization (T1 - ESA) }\end{array}$ & $96.07 \pm 0.99^{\mathrm{aA}}$ & $91.70 \pm 3.17 \mathrm{aB}$ & $1333.03 \pm 209.61^{\mathrm{cA}}$ & $1237.80 \pm 110.87^{\mathrm{aA}}$ & $95.89 \pm 0.00^{\mathrm{aA}}$ & 82.13 \\
\hline $\begin{array}{l}\text { Water stress with organic } \\
\text { fertilization (T2 - ECAO) }\end{array}$ & $94.46 \pm 0.73^{\mathrm{bA}}$ & $58.18 \pm 0.51^{\mathrm{cB}}$ & $1731.68 \pm 337.79^{\mathrm{bA}}$ & $1383.24 \pm 7.93^{\mathrm{aB}}$ & $95.89 \pm 0.00^{\mathrm{aA}}$ & $15.71 \pm 0.56^{\mathrm{dB}}$ \\
\hline $\begin{array}{l}\text { Water stress with mineral } \\
\text { fertilization (T3 - ECAM) }\end{array}$ & $61.82 \pm 0$ & $58.54 \pm 1.50^{\mathrm{cA}}$ & $1297.54 \pm 224.22^{\mathrm{cA}}$ & $842.18 \pm 3$ & $95.89 \pm 0.00^{\mathrm{aA}}$ & $27 \pm 4.30^{\mathrm{cB}}$ \\
\hline $\begin{array}{l}\text { No fertilization and no water } \\
\text { stress (T4 - SASE) }\end{array}$ & $67.09 \pm 1.21^{\mathrm{dA}}$ & $52.48 \pm 5.46^{\mathrm{eB}}$ & $979.40 \pm 525.99^{\mathrm{dA}}$ & $789.81 \pm 60.14^{\mathrm{cB}}$ & $43.15 \pm 0.17^{\mathrm{bA}}$ & $30.12 \pm 1.24^{\mathrm{cB}}$ \\
\hline $\begin{array}{l}\text { Organic fertilization without } \\
\text { water stress (T5 - AOSE) }\end{array}$ & $91.67 \pm 0.38^{\mathrm{cA}}$ & $70.22 \pm 0.94^{\text {bB }}$ & $1925.59 \pm 37.68^{\mathrm{aA}}$ & $880.71 \pm 41.23^{\mathrm{cB}}$ & $95.89 \pm 0.00^{\mathrm{aA}}$ & $17.18 \pm 0.92^{\mathrm{dB}}$ \\
\hline $\begin{array}{l}\text { Mineral fertilization without } \\
\text { water stress (T6 - AMSE) }\end{array}$ & $94.01 \pm 0.40^{\mathrm{bA}}$ & $58.50 \pm 3.27^{\mathrm{cB}}$ & $2058.47 \pm 179.56^{\mathrm{aA}}$ & $1036.1 \pm 64.67^{\mathrm{bB}}$ & $95.89 \pm 0.00^{\mathrm{aA}}$ & $48.36 \pm 3.34^{\text {bВ }}$ \\
\hline
\end{tabular}

Means followed by the same lowercase letters in the columns (between "leaf" and "root" of each analysis: antioxidant, phenolic compounds, flavonoids) and uppercase letters in the rows do not differ from each other by the Scott-knot test at $5 \%$ probability. Legend: *No significant effect on leaf extract in the different cultivations. 
A study with seed extracts (buffer - sodium acetate, $\mathrm{HCl}$, and glycine) from Brasica juncea (mustard), a species belonging to the same family of $R$. sativus, identified trypsin and chymotrypsin inhibitory activity; anticancer and antiinflammatory activity; and ability to reduce triglycerides, serum total cholesterol, LDL, and VLDL (Serquiz, Morais, Sátiro, \& Serquiz, 2017).
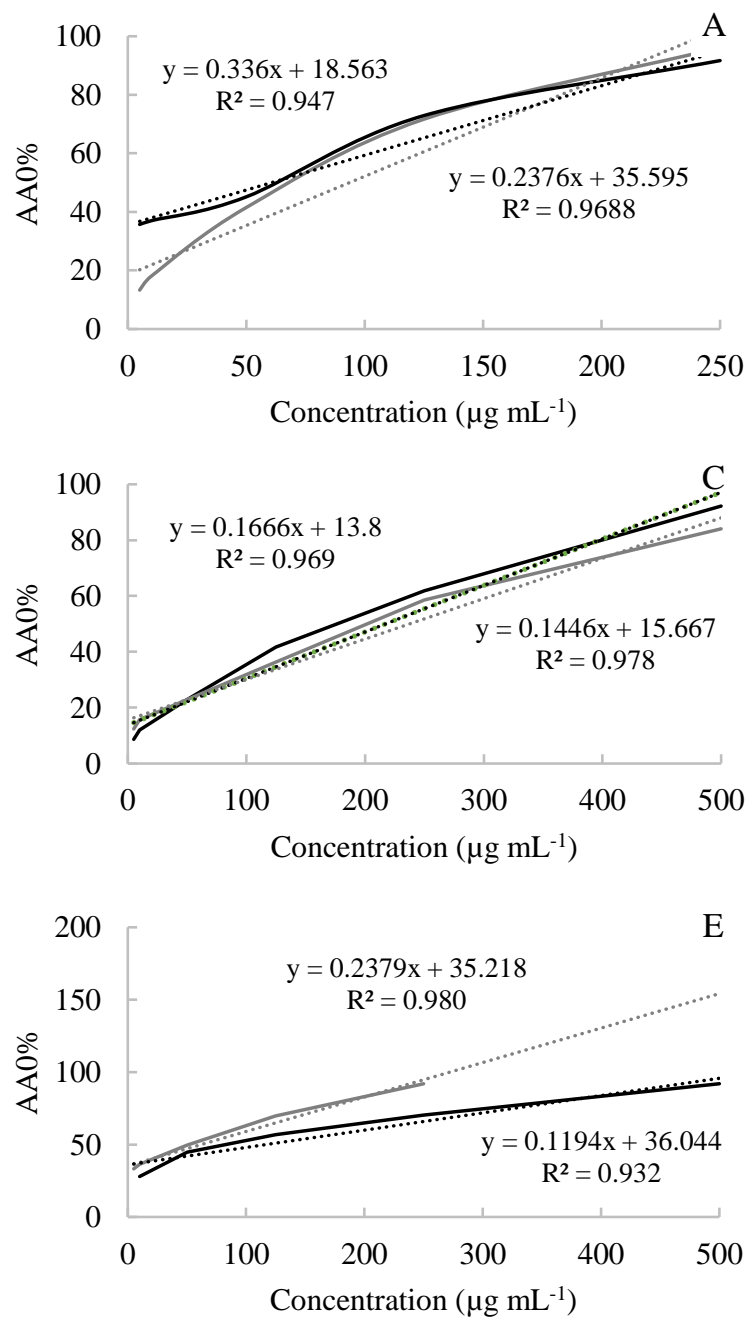

The DPPH test results suggest that the evaluated leaf and root extracts had antioxidant capacity (Table 2 ). There was a high correlation between the increase in antioxidant percentage of $R$. sativus leaves and roots and the variation of extract concentration, where the determination coefficients ranged from 0.89 to 0.98 (leaf) and 0.93 to 0.97 (root; Figure $1)$.
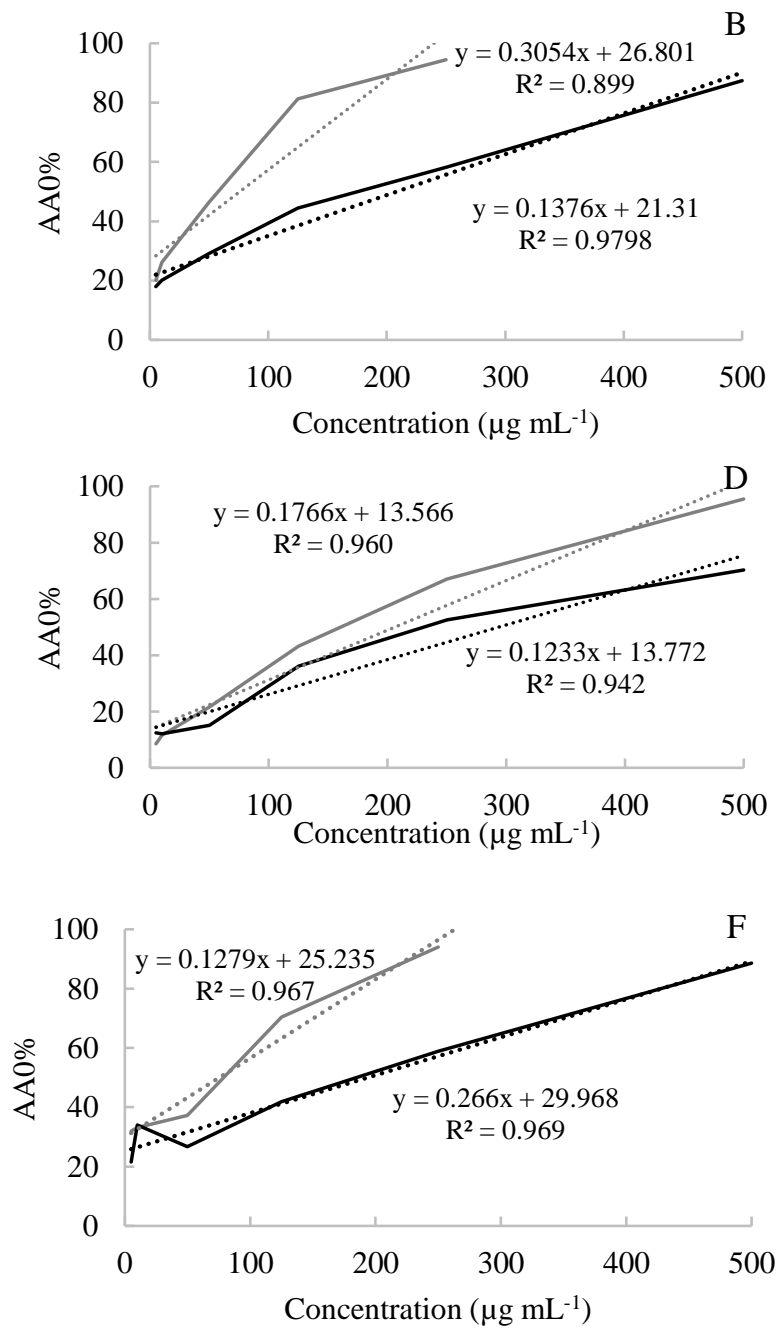

Figure 1. Graphs of the antioxidant potential (AA0\%) of R. sativus leaf (gray line) and root (black line) extracts under different growing conditions. A: water stress without fertilization; B: water stress with organic fertilization; C: water stress with mineral fertilization; D: no fertilization and no water stress; E: organic fertilization without water stress; F: mineral fertilization without water stress.

The data (Figure 1) were obtained from statistical analysis. In all graphs, $\mathrm{R}^{2}$ values were close to 1.0 , indicating that the equation of the generated line effectively reproduces the behavior of samples regarding their antiradical activity.

$R$. sativus extracts grown under water stress and without fertilization showed higher antioxidant potential (Table 2). Water stress is an abiotic factor that induces the production of phenolic compounds as the plant tends to produce defense substances against unfavorable factors present in the environment (Rigueira, Bandeira, Chagas, \& Milagres, 2016).

Leaf extracts showed higher DPPH radical scavenging activity. When evaluating methanolic extracts of leaves and stems of Brassica oleracea L. var. acephala (kale) in organic and conventional systems, Rigueira et al. (2016) also observed greater antioxidant potential in leaves.

When evaluating the ethanolic extract of $R$. sativus stems $\left(0.01 \mathrm{~g} \mathrm{~mL}^{-1}\right)$, Melo and Faria (2014) obtained an antioxidant activity of $29.06 \pm 1.11 \%$, lower than the value found in the samples studied here. In turn, studying the antioxidant potential of the ethanolic extract of $R$. sativus roots at a concentration of $0.02 \mathrm{~g} \mathrm{~mL}^{-1}$, Tiveron (2010) found a percentage of $9.8 \pm 0.33 \%$.

Compared to the data presented in the literature, the radish root samples evaluated in this study showed higher DPPH free radical scavenging activity, suggesting that environmental factors, fertilization, and water stress may 
have influenced the results observed for antioxidant capacity. When evaluating vegetables in conventional and organic systems, Rigueira et al. (2016) and Arbos, Freitas, Stertz, \& Dornas (2010) found that vegetables under organic fertilization tend to have higher antioxidant activity.

Moreover, studying the methanolic extract of $B$. oleracea leaves at a concentration of $0.1 \mathrm{~g} \mathrm{~mL}^{-1}$, in organic and conventional systems, Rigueira et al. (2016) found a percentage of DPPH reduction equal to $68.6 \pm 1.2$ and $44.7 \pm$ $1.8 \%$, respectively. When evaluating the antioxidant activity of Eruca sativa (arugula) in an organic system, Arbos et al. (2010) identified an antioxidant potential higher than $70 \%$, at a concentration of $1 \mathrm{mg} \mathrm{mL}^{-1}$.

The results obtained for the leaves of $R$. sativus suggest its phytotherapeutic importance due to its high efficiency as antioxidant. Nevertheless, research on its medicinal properties is scarce.

In addition, $R$. sativus tuber has medicinal properties such as acting as an expectorant and a stimulant of the digestive system, containing vitamins A, C, B1, B2, B6, folic acid, potassium, calcium, phosphorus, and sulfur. It is rich in dietary fiber, has low caloric content, and is a source of antioxidant compounds (Rodrigues, Pizetta, Teixeira, Reis, \& Hott, 2013).

As in the DPPH radical scavenging test, the roots presented higher production of phenolic compounds when subjected to water stress without fertilization, and except for plants under this treatment, phenolic content was higher for leaves compared to roots.

Thus, comparing the antioxidant potential by the DPPH method and the results of phenolic compounds content, it turns out that one justifies the other. In other words, one of the factors that influence the antioxidant potential of vegetables comes from the concentration of secondary metabolites, especially phenolic compounds, which are characterized by their high antioxidant activity (Soethe, Steffen, Amarante, Martin, \& Bortolini, 2016).

Environmental factors such as temperature, water availability, type of fertilization, and light exposure interfere with the production of antioxidant compounds by plants. The use of organic fertilizer keeps the vegetables free from the application of chemicals and consequently allows the development of pests, which generates a greater synthesis of phenolic compounds in the plant as a defense against pathogen attack. The same is observed for water stress, which generates in the plant an adverse situation triggering the production of phenolics as a form of defense against the abiotic factor (Rigueira et al., 2016).

When evaluating the ethanolic extract of $R$. sativus stems (0.01 $\left.\mathrm{g} \mathrm{mL}^{-1}\right)$, Melo and Faria (2014) obtained a phenolic compounds content of $7.64 \pm 0.64 \mathrm{mg} \mathrm{GAE} / \mathrm{g}$ extract. One of the aspects that may explain this difference is possibly the action of abiotic factors such as water stress and fertilization. Arbos et al. (2010) identified a content of $126.86 \pm 4.46 \mathrm{mg}$ GAE $100 \mathrm{~g}^{-1}$ in the methanolic extract of $E$. sativa leaves grown in a conventional system. Studying the methanolic extract of $B$. oleracea leaves $\left(0.1 \mathrm{~g} \mathrm{~mL}^{-1}\right)$ in an organic system, Rigueira et al. (2016) found a content of 181.5 $\pm 14.2 \mathrm{mg} \mathrm{GAE}$ $100 \mathrm{~g}^{-1}$.

It is noticeable that the extracts grown under organic fertilization and mineral fertilization, both without water stress, showed equal values of phenolic compounds for the leaf. In turn, the extracts of plants grown under water stress and organic fertilization showed higher phenolic content in leaf and root compared to those of plants grown under water stress and mineral fertilization. Thus, it is assumed that organic fertilization influences the concentration of phenolic compounds in vegetables. According to Arbos et al. (2010), vegetables grown in an organic system tend to have a higher phenolic compounds content.

There was a significant effect for root among the different growing conditions. Plants developed under water stress and without fertilization showed higher flavonoids content, phenolic compounds content, and antioxidant potential. The antiradical capacity of roots under water stress and without fertilization is justified by the content of phenolic compounds and flavonoids present in the tuber.

According to Bomfim et al. (2017), the antioxidant potential of vegetables comes from phenolic compounds. When studying a group of vegetables and fruits, these authors found a correlation between antioxidant activity and polyphenol content.

\section{Conclusion}

Abiotic factors (water availability and cultivation system) influence both production and concentration of secondary metabolites. $R$. sativus plants grown under organic fertilization and without water stress showed high phenolic content. $R$. sativus extracts grown under water stress and without fertilization showed higher antioxidant potential and flavonoids content, respectively.

The relationship between antioxidant potential and the concentration of bioactive compounds such as phenolic and flavonoid compounds became evident. Leaf extracts of $R$. sativus showed high antioxidant potential.

\section{References}

Arbos, K. A., Freitas, R. J. S., Stertz, S. C., \& Dornas, M. F. (2010) Atividade antioxidante e teor de fenólicos totais em hortaliças orgânicas e convencionais. Revista Ciência e Tecnologia de Alimentos, 30(2), 501-506. doi:10.1590/S0101-20612010000200031

Barros, R. P., Reis, L. S., Costa, J. G., Cunha, A. L., Magalhaes, I. C. S. Silva, C. G., Santos, A. F., Neves, J. D. S., Duarte, A. G., Mello, G. S V., Freitas, J. D., Sousa, J. S., \& Franco, S. P. B. (2018). Bioactivity and phenolic composition of extracts of noni (Morinda citrifolia L. Rubiaceae) in tomato moth (Tuta absoluta Meyrick, 1917) (Lepidoptera: Gelechiidae). African Journal of Agricultural Research, 13(39), 2063-2069. doi:10.5897/AJAR2018.13447

Bomfim, M. P., Lima, G. P. P., Vianelo, F., \& São José, A. R. (2017). Characterization of bioactive compounds in fruits ande vegetables purchased in the Padova - Itália. Revista Iberoamericana de Tecnología Postocosecha, 18(2), 1-17.

Coutinho Neto, A. M., Orioli Junior, V., Cardoso, S. S., \& Coutinho, E. Z. M. (2010). Produção de matéria seca e estado nutricional do rabanete em função da adubação nitrogenada e potássica. Revista Nucleus, 7(2): 105- 114. http://dx.doi.org/10.3738/nucleus.v7i2.349

Dutra, M., Deboni, T. C., Volpi, P. S. B., Matias, J. F. G., \& Nesi, B. Z. (2014). Avaliação produtiva de rabanete Raphanus sativus L. submetido a preparados homeopáticos de tiririca Cyperus rotundus $\mathrm{L}$. Revista Brasileira de Agroecologia, 9(2), 151-159.

Ferreira, D. F. (2014). Sisvar: a Guide for its Bootstrap procedures in multiple comparisons. Ciência e Agrotecnologia., 38(2), 109112. doi:10.1590/S1413-70542014000200001 
Melo, C. M. T., \& Faria, J. V. (2014). Composição centesimal, compostos fenólicos e atividade antioxidante em partes comestíveis não convencionais de seis olerícolas. Bioscience Journal., 30(1), 93-100.

Rigueira, G. D. J., Bandeira, A. V. M., Chagas, C. G. O., \& Milagres, R. C. R. M. (2016). Atividade antioxidante e teor de fenólicos em couve-manteiga (brassica oleracea l. var. acephala) submetida a diferentes sistemas de cultivo e método de preparo. Semina: Ciências Biológicas e da Saúde, 37(2), 3-12. http://dx.doi.org/10.5433/1679-0367.2016v37n2p3

Rodrigues, R. R., Pizetta, S. C., Teixeira, A. G., Reis, E. F., \& Hott, M. O. (2013). Produção de rabanete em diferentes disponibilidades de água no colo. Enciclopédia Biosfera, 9(17), 2121-2130.

Santos, A. F. , Cunha, A. L. , Melo, I. S. V. de , Pavão, J. M. S. J. , Costa, J. G., \& Franco, S. P. B. (2019). Análise do potencial antioxidante de três espécies vegetais da família Fabacea. In: Alan Mario Zuffo. (Org.), As Regiões Semiáridas e suas Especificidades. (1ed., Cap. 8, pp.70 - 84). Ponta Grossa: Atena. doi:10.22533/at.ed.923191503

Schlickmann, F. (2015). Estudo químico e avaliação do potencial gastroprotetor, antinociceptivo e antiploriferativo de Mimusops balata (Abricó-da-praia) (Dissertação de mestrado). Universidade do Vale do Itajaí. Itajaí, Santa Catarina.

Serquiz, R. P., Morais, A. M. A., Sátiro, D. S. P., \& Serquiz, A. C. (2017). Avaliação do potencial biológico e farmacológico (determinação das atividades hemaglutinante e inibidora de proteases) de sementes de mostarda. Revista da Saúde \& Biotecnologia, 1(1), 31-47.

Silva, A. F. (2014). Estudo farmacognóstico e avaliação das atividades biológicas de Raphanus sativus var. oleiferus Metzg (Dissertação de mestrado). Universidade Federal de Alfenas, Alfenas, Minas Gerais.

Singh, P.\& Singh, J. (2013). Medicinal and therapeutic utilities of Raphanus sativus. International Journal of Plant, Animal and Environmental Sciences, 3(2), 103-105.

Soethe, C., Steffens, C. A., Amarante, C. V. T., Martin, M. S., \& Bortolini, A. J. (2016). Qualidade, compostos fenólicos e atividade antioxidante de amoras-pretas 'Tupy' e 'Guarani' armazenadas a diferentes temperaturas. Revista Pesquisa Agropecuária Brasileira, 51(8), 950-957. doi:10.1590/S0100-204X2016000800007

Sousa, R. F.\& Sousa, J. A. (2017). Metabólitos secundários associados a estresse hídrico e suas funções nos tecidos vegetais. Revista Brasileira de Gestão Ambiental, 11(1), 1-8.

Sociedade brasileira de ciência do solo (2004). Manual de adubação e de calagem para os Estados do Rio Grande do Sul e de Santa Catarina ( 10 ed.). Porto Alegre: Sociedade Brasileira de Ciência do Solo.

Tiveron, A. P. (2010). Atividade antioxidante e composição fenólica de legumes e verduras consumidos no Brasil (Dissertação de mestrado) Universidade de São Paulo - Escola Superior de Agricultura "Luiz Queiroz”, Piracicaba, São Paulo. doi:10.11606/D.11.2010.tde-20102010101541

Valério, S. H. (2017). Glicosinolatos: Estrutura Química, Mecanismo de Ativação Enzimática e Atividade Biológica (Monografia). Universidade Federal de São João del-Rei, São João del-Rei, Minas Gerais.

\section{License: Creative Commons CC BY 4.0}

This article was published with open access for distribution under the terms of the Creative Commons Attribution License, which allows unrestricted use, distribution, and reproduction in any medium, provided the original work is properly cited. 